\title{
Parents' Reasons for Sending Their Child to Montessori Schools
}

\author{
Elisabeth Hiles \\ Boston College
}

Keywords: School choice, Montessori education, parental decision-making, school administrators

\begin{abstract}
Although the Montessori Method of education is more than 100 years old, the number of Montessori schools in the United States has exponentially increased since 1990. Montessori methods and practices can be complex and difficult for parents to understand, even among parents whose child attends Montessori schools. Moreover, it is unclear why parents decide to enroll their child in Montessori schools. This study presents the results of a survey administered to 124 parents whose children were enrolled in 3 Montessori schools in Massachusetts. Findings indicate that 4 reasons motivated parents' choice of Montessori education: attraction to Montessori principles, perceived fit with the Montessori philosophy or school, anticipated outcomes, and attraction to the Montessori classroom. These findings indicate that, to support parents' decision-making, Montessori administrators should invest in parental and public awareness about Montessori education and provide prospective families with specific information related to school fit, classroom environment, and long-term student outcomes.
\end{abstract}

The Montessori Method is a comprehensive, child-centered philosophy of education rooted in developmental psychology. It was created in the early 1900s by Maria Montessori in Rome, Italy. Although the Montessori Method was introduced in the United States in 1911 (Povell, 2010), resistance from progressive educators such as John Dewey and William Heard Kilpatrick caused its use and popularity to decline. The Montessori Method reappeared in the late 1950s and early 1960s (Chertoff, 2012); since then, the number of Montessori schools in the United States has continued to grow, despite a general lack of research on its benefits, outcomes, and implementation (A. Lillard, 2012; National Center for Montessori in the Public Sector, 2014). Currently, there are over 22,000 Montessori schools in 110 countries worldwide (American Montessori Society, n.d.), and approximately 4,500 of these are located in the United States (North American Montessori Teachers’ Association [NAMTA], n.d.).

Despite resurgence of the Method, Montessori schools and their educational methods remain difficult for many to comprehend, and misconceptions about the Montessori Method abound (NAMTA, n.d.). In her survey of 1,520 American adults, Murray (2008) found widespread misunderstanding about how Montessori classrooms are structured, about what goes on in classrooms, and about the roles teachers play. Hiles (2015) discovered misunderstanding of Montessori theory and practice, even among parents who enrolled their child in Montessori schools. Thus, it is important to examine why parents select Montessori education for their child. For example, the 2016 incidence of the "Prince George effect," in 
which record numbers of London-area parents flocked to Montessori schools in the wake of Prince George's enrollment in Montessori preschool (Perry, 2016), suggests that parents' choice of Montessori may-for some- be the latest celebrity-inspired fad.

Given the relative lack of accurate knowledge among adults about Montessori schools, it is unclear why parents enroll their child in these schools. The author of this study set out to uncover these reasons as a means to better understand Montessori parents and to create stronger school-family relationships.

\section{Montessori Education}

The Montessori Method was introduced in the United States in 1911 amid enthusiasm and excitement for the novel teaching approach (Povell, 2010). However, the onset of World War I and criticism from prominent American educators, particularly John Dewey and William Heard Kilpatrick, arrested the spread of the movement until its reemergence in the late 1950s and early 1960s (Chertoff, 2012; Whitescarver \& Cossentino, 2008). Considerable expansion of the Method occurred in recent decades in the United States (Dohrmann, 2003), where today there are approximately 4,500 Montessori schools (NAMTA, 2014). The majority of these schools serve children in preschool through kindergarten, with fewer extending to eighth grade and even fewer including high school years.

Underlying the Montessori Method are six interdependent and interacting Montessori principles that inform how classrooms are structured and organized, the roles of teachers and children, and how learning transpires (see Table 1).

Few peer-reviewed studies have examined the efficacy and outcomes associated with Montessori education in the United States (Marshall, 2017). Moreover, the majority of existing studies are plagued by methodological limitations, such as absence of longitudinal data, difficulty in determining causality for any observable outcomes, use of small homogenous samples, problems with defining the essential characteristics of a Montessori classroom, and differences in the number of years each participant surveyed had attended Montessori schools. The evidence base for Montessori education also lacks randomized control trials.

Early studies from the 1970s through the 1990s largely focused on preschool-age children and are of little research significance due to poor design, limited scope, and small sample sizes (Chattin-McNichols, 1992; A. Lillard \& Else-Quest, 2006). Four later studies examined academic outcomes for elementary and middle school Montessori students (Dohrman, 2003; A. Lillard \& Else-Quest, 2006; Lopata, Wallace, \& Finn, 2005; Rathunde, 2003). Results from these later studies indicated that Montessori students enjoy learning and working hard and appreciate a positive, community-based classroom environment. Although results were mixed across the four studies, evidence also suggested that Montessori students perform better than traditionally educated children in mathematics, language arts, and problem-solving.

Rathunde (2003) examined comparative groups of middle school students attending Montessori and traditional middle schools. Students recorded their mood, energy levels, feelings of importance, sense of enjoyment, and flow eight times a day for 7 consecutive days. Results indicated that Montessori middle school students overall had a higher quality educational experience than did traditional middle school students. Rathunde concluded that Montessori students had learned to better enjoy working hard, liked their teachers more, and felt more connected to their classmates compared to students in traditional schools.

Dohrmann (2003) compared standardized test scores and grade point averages for high school graduates $(N=201)$, including an experimental group that attended Montessori programs through at least fifth grade and a control group that attended traditional programs. The Montessori group significantly outperformed the control group in math and science on the ACT and on the Wisconsin Knowledge and Concepts Examination (a national standardized test administered in tenth grade). Differences in grade point averages also approached significance, favoring Montessori students. In contrast, Lopata et al.'s (2005) study of academic achievement of 543 urban fourth- and eighth-grade students who attended either Montessori or traditional education programs revealed mixed results for math and language arts achievement. 
Table 1

Montessori Principles, Manifestations, and Outcomes

\begin{tabular}{|c|c|c|}
\hline Principle & Observable manifestations & Purported outcomes \\
\hline $\begin{array}{l}\text { Respect for the child } \\
\text { (Morrison, 2014; Schmidt } \\
\text { \& Schmidt, 2009) }\end{array}$ & $\begin{array}{l}\text { Children are supported in: } \\
\text { Doing and learning things for } \\
\text { themselves without unnecessary help } \\
\text { or interruption } \\
\text { Having long time blocks during the day } \\
\text { Choosing their own materials } \\
\text { Working at their own pace } \\
\text { Becoming fully engrossed in what they } \\
\text { are working on }\end{array}$ & $\begin{array}{l}\text { Learning autonomy } \\
\text { Positive self-esteem } \\
\text { Self-discipline }\end{array}$ \\
\hline $\begin{array}{l}\text { Support for absorbent mind } \\
\text { (Morrison, 2014; } \\
\text { Montessori, 1995) }\end{array}$ & $\begin{array}{l}\text { Classroom environment and experiences } \\
\text { help children soak up as many } \\
\text { experiences as possible }\end{array}$ & $\begin{array}{l}\text { Heightened learning } \\
\text { experience }\end{array}$ \\
\hline $\begin{array}{l}\text { Allowance of sensitive periods } \\
\text { (Enright, 2010; Seldin \& } \\
\text { Davies, 2006) }\end{array}$ & $\begin{array}{l}\text { Children are allowed to intensely focus } \\
\text { their energy and attention on specific } \\
\text { aspects of the environment to the } \\
\text { exclusion of others }\end{array}$ & $\begin{array}{l}\text { Passion } \\
\text { Commitment } \\
\text { Often leads to mastery }\end{array}$ \\
\hline $\begin{array}{l}\text { Support for auto-education } \\
\text { (International Montessori } \\
\text { Council, n.d.; Morrison, } \\
\text { 2014) }\end{array}$ & $\begin{array}{l}\text { Curriculum features: } \\
\text { Children teaching themselves } \\
\text { Self-directed curriculum } \\
\text { Avoidance of external rewards } \\
\text { Absence of preselected courses of study }\end{array}$ & $\begin{array}{l}\text { Natural curiosity } \\
\text { Intrinsic motivation to } \\
\text { learn }\end{array}$ \\
\hline $\begin{array}{l}\text { Prepared environments } \\
\text { (NAMTA, 2014; Schmidt } \\
\text { \& Schmidt, 2009) }\end{array}$ & $\begin{array}{l}\text { Well-organized and equipped classroom } \\
\text { Availability of didactic, hands-on, and } \\
\text { developmentally appropriate materials } \\
\text { Immediate learning feedback }\end{array}$ & $\begin{array}{l}\text { Stimulate brain } \\
\text { development } \\
\text { Independent learning and } \\
\text { exploration } \\
\text { Engagement of all } \\
\text { sensorial functions }\end{array}$ \\
\hline $\begin{array}{l}\text { Protection of child's right to } \\
\text { learn } \\
\text { (Enright, 2010; Montessori, } \\
\text { 1995) }\end{array}$ & $\begin{array}{l}\text { Lead teacher: } \\
\text { Closely monitors each child's } \\
\text { development } \\
\text { Keeps child supplied with appropriately } \\
\text { challenging learning opportunities } \\
\text { Keeps child supplied with materials and } \\
\text { works suitable to the child's strengths }\end{array}$ & $\begin{array}{l}\text { Steady development and } \\
\text { learning }\end{array}$ \\
\hline
\end{tabular}

A. Lillard and Else-Quest (2006) examined standardized testing results for Montessori and traditional students at ages 5 and 12. Montessori students at age 5 performed significantly better in letterword identification, word attack, and math skills. Picture vocabulary, basic thinking, and concept skills showed no difference. Among the group of 12-year-olds, Montessori students had more sophisticated 
writing and language skills and displayed a stronger sense of both community and caring for their peers but did not exhibit higher test scores (A. Lillard \& Else-Quest, 2006).

A. Lillard and Heise (2016) examined the effect of using only Montessori materials in a preschool classroom compared to using both Montessori and non-Montessori materials. They found that students from classrooms in which non-Montessori supplementary materials had been removed made greater gains on assessed measures over 4 months than students from the classrooms with mixed materials. This study is critical in light of other studies that have reported little or no difference in gains for students from Montessori versus non-Montessori classrooms (Laski, Vasilyeva, \& Schiffman, 2016).

More recently, A. Lillard et al. (2017) conducted a longitudinal study of two public Montessori magnet schools in a high-poverty American city. The sample consisted of 141 students, 70 of whom were enrolled in the two Montessori schools. Students were tested four times in 3 years (i.e., annually from ages 3 to 6) on various cognitive and socioemotional measures. Notably, no significant differences emerged on the initial tests. However, the Montessori preschool students scored better on subsequent tests of academic achievement, social understanding, and mastery orientation, and they reported liking scholastic tasks more. Differences in academic achievement between lower-income Montessori students and higher-income, traditionally schooled students shrank at each assessment and were not statistically significant by the end of the study period. Students with lower and higher executive function also scored equally on assessments of academic achievement. This result is notable because researchers have suggested that executive function predicts academic achievement (Koster-Hale \& Saxe, 2013). Based on their own findings, A. Lillard et al. (2017) concluded that Montessori education can elevate and equalize important outcomes.

\section{Choice of Educational Options}

Parents in the United States have a wide variety of choices for educating their child, including several types of public and private schools, as well as home- and self-education options.

\section{Public Schools}

Public schools are universally available and are government-run via state-level departments of education, local school districts and school boards, and federal oversight. Because tuition is paid through tax revenue, parents of enrolled students do not pay tuition directly to the school. Oversight and funding for public schools occur at the federal level by the U.S. Department of Education, at the state level by statebased departments of education, and at the local level by the school districts. As of the 2014-2015 school year, there were 13,601 public school districts and nearly 98,176 public schools across all 50 states (U.S. Department of Education, 2016b). Each state directs its school districts in matters concerning educational standards and standardized testing, while each school district manages the curricula, funding, and employment for the schools within its boundaries. There are three main types of public schools: neighborhood schools, charter schools, and magnet schools. Public Montessori schools also exist.

\section{Private Schools}

Private schools are revenue-generating schools that charge tuition and tend to control curriculum requirements more than public schools do (Anderson \& Resnick, 1997). Several different options are available within private schools, such as traditional preparatory schools, parochial schools, and alternative schools (including Montessori and Waldorf schools).

\section{Parental Choice}

During the 2013-2014 school year, there were an estimated 131,890 K-12 schools in the United States, including 98,271 public and 33,619 private schools (U.S. Department of Education, 2016b). In the same year, more than 50 million students attended public elementary and secondary schools (U.S. 
Department of Education, 2016c), and 5.8 million students attended private schools for pre-Kindergarten through grade 12 in 2015 (U.S. Department of Education, 2016a). Although statistics on student enrollments are available across the various educational options, the issue of why parents choose one option over another would benefit from continued exploration (Hiles, 2015).

Relevant to the present study is that many adults do not know about Montessori education (Murray, 2012), and those who do are subject to a number of misconceptions. In particular, Murray's (2008) online survey of a demographically representative sample of 1,520 adults revealed that respondents believed external incentives such as grades and stickers were necessary rewards to encourage learning, whereas Montessori philosophy asserts that learning an activity is its own reward (Hainstock, 1997). Additionally, respondents did not understand the design and structure of the Montessori classroom or children's need for long blocks of uninterrupted work time.

Common misconceptions about the Montessori Method among those who have heard about the philosophy include: (a) Montessori schools are only for preschoolers or special learners (Lopata et al., 2005; NAMTA, 2014), (b) the Montessori Method is not widely accepted, and (c) Montessori classrooms are relatively unsupervised and children are free to do whatever they want (P. Lillard, 1997; NAMTA, 2014). Other misconceptions are that Montessori schools have a religious orientation, are only for the rich, or fail to adequately challenge students (NAMTA, 2014).

Given the relative lack of accurate knowledge among adults about private Montessori schools, it is unclear why parents enroll their child in these schools. This study set out to uncover these reasons to provide better understanding of Montessori parents and to support stronger school-family relationships.

\section{Methods}

The participants in this study were parents and guardians whose child attended one of three Montessori schools that enroll toddlers through eighth graders. The three schools had a combined student population of 597 students from 375 families. Parents and guardians from the three target schools received a letter via email from their respective heads of schools inviting them to participate in a survey. Parents and guardians of each enrolled child were invited to take part in the survey. The letter included a link to a secure online survey that was available for 2 weeks. This study used a convenience sample based on voluntary responses to the survey. No other sampling procedures were used.

To maintain participant confidentiality, the only demographic information the survey gathered was the year the respondent first enrolled a child in a Montessori school. Because no other demographic data were collected, the number of families represented in the survey and the ages of respondents' children are unknown. Respondents' length of involvement with their Montessori schools ranged from 3 months to 17 years $(M=5.41$ years, $S D=3.69)$.

The survey data for this study were gathered using one open ended question: Why did you decide to send your child to a Montessori school? Parents could choose whether or not to answer the survey questions, and 124 responses were gathered.

I examined and coded the open-ended responses using content-analysis procedures described by Miles, Huberman, and Saldaña (2013). First, I created an initial codebook by gathering and summarizing data about Montessori principles from books and articles about the Montessori Method. Based upon this examination, I outlined the six founding principles, observable characteristics, and outcomes widely associated with the Montessori philosophy and its classrooms (see Table 1).

I then examined participants' responses, extracted meaning units, and coded them using the codebook. Codes were removed, adapted, or added to the codebook as needed to best fit the data. Next, I reorganized the data by code and then reviewed and revised the results as needed until the analysis best fit the data. Upon completion of the analysis, I calculated the number of participants reporting each code. The final analysis was examined by a second coder to enhance validity. 


\section{Results}

The data indicated that participants chose to send their child to Montessori school for four reasons: attraction to Montessori principles ( $n=70,56.5 \%)$, perceived fit with the philosophy or school $(n=64$, $51.6 \%)$, anticipated valuable outcomes $(n=50,40.3 \%)$, and attraction to the Montessori classroom $(n=40$, $32.3 \%)$. These reasons are fully discussed in the following sections.

\section{Attraction to Montessori Principles}

Analysis of respondents' freeform responses indicated that more than half of them $(n=70,56.5 \%)$ sent their child to Montessori school because of their attraction to specific Montessori principles (see Table 2). Of these 70 respondents, roughly half were attracted to the concepts of auto-education (52.9\%) and respect for the child (50.0\%).

Table 2

Parents’ Positive Perceptions of Montessori Principles Influencing Choice of School (n = 70)

\begin{tabular}{|c|c|c|}
\hline Principle & $n$ & $\%$ \\
\hline Auto-education $^{\mathrm{a}}$ & 37 & $52.9 \%$ \\
\hline Respect for the child ${ }^{b}$ & 35 & $50.0 \%$ \\
\hline Prepared environments and hands-on, didactic materials & 9 & $12.9 \%$ \\
\hline Teacher role & 9 & $12.9 \%$ \\
\hline Sensitive periods & 3 & $4.3 \%$ \\
\hline Absorbent mind & 1 & $1.4 \%$ \\
\hline
\end{tabular}

Note. Parents' open-ended responses were analyzed, and some parents' responses corresponded to two or more principles.

${ }^{\text {a }}$ Twenty-eight parents specified the subtheme of wanting their child to be able to engage in self-directed study and independent exploration. ${ }^{b}$ Nineteen parents specified the subtheme of wanting their child to be able to work at their own pace, whether that was faster or slower than other children's pace.

The most frequently cited principle, auto-education, refers to self-directed exploration and learning. Respondents explained that they wanted their child to choose their own learning topics and become an independent learner, rather than follow a preselected course of study. One respondent explained,

I wanted my children to be allowed to learn at the pace dictated by their own abilities and not by a preset curriculum.... Our younger child loves to push ahead to master concepts that are not taught in her grade at other local schools.

The second most-commonly cited principle was respect for the child, which refers to helping children do and learn things for themselves without unnecessary help or interruption and allowing children long blocks of time during the day to choose their own materials and become fully engaged in their work. Notably, 19 of the 35 respondents who mentioned respect for the child stressed their desire to let their child work at their own pace, whether faster or slower than that of peers. One respondent explained, "It gave him the extra time he needed to catch up on academics at his own pace," while another stated, "We thought our genius-IQ child could progress at his own rate.” 


\section{Perceived Fit With Philosophy or School}

Nearly half of respondents $(n=55,44.3 \%)$ stated they chose their school because of their child's fit with Montessori philosophy or the school itself. More than half of this group $(n=35,54.7 \%)$ reported that their positive perceptions and experiences of Montessori education prompted their enrollment decision (see Table 3). For this analysis, experiences refers to firsthand experiences or observations, others' experiences, or others' recommendations related to Montessori education in general, to other Montessori schools, or to the school the parents chose.

Table 3

Perceptions of School Fit Prompting Parents’ Choice of Montessori $(\mathrm{n}=64)$

\begin{tabular}{|c|c|c|}
\hline Perception of fit & $n$ & $\%$ \\
\hline $\begin{array}{l}\text { Positive perceptions and experiences of Montessori education } \\
\text { Overall educational philosophy (12) } \\
\text { With other Montessori schools (13) } \\
\text { With the school chosen (12) }\end{array}$ & 35 & 54.7 \\
\hline $\begin{array}{l}\text { School fit parents' and/or child’s needs } \\
\text { Approach fit child’s learning style (10) } \\
\text { Wanted education-based rather than play-based preschool (7) } \\
\text { Convenient location (6) }\end{array}$ & 22 & 34.4 \\
\hline $\begin{array}{l}\text { Other options were believed to undermine child's learning or not fit needs } \\
\text { Deleterious instructional approaches (6) } \\
\text { Poor classroom and social environment (6) } \\
\text { Other unmet needs (5) } \\
\text { Lower educational quality (4) }\end{array}$ & 19 & 29.7 \\
\hline
\end{tabular}

Note. Parents' open-ended responses were analyzed, and some parents' responses corresponded to two or more principles.

a“Perceptions and experiences” refers to firsthand experience, others' experiences, or others' recommendations.

For example, 12 parents reported that the overall Montessori philosophy appealed to them. One respondent stated, "I believe it is a powerful way to approach education, and that its strategies mirror the latest brain-based research on how children (and people) learn.” Other respondents were educators and had concluded that the Montessori approach was superior to traditional education. One participant said, "I am an educator who has worked in traditional public schools and progressive private schools. I also felt Montessori teachers are the most highly trained teachers in both skills and child development.”

Nine respondents reported that they or their spouse had attended Montessori school as a child, their child had been enrolled in another Montessori school in the past, or they had friends at the school. One respondent said, "Both parents attended and we thought it would be a good fit for our son." Another respondent stated, "We had friends with other children at the school." School reputation also influenced parental choice. One respondent explained, "It was a high quality, small school with a great reputation. That it was Montessori was a bonus; it was after we discovered the school that we realized how ideal the Montessori philosophy is.”

Perceived fit also included parents' perceptions that the school fit their child's or their own needs (34.4\%). Ten respondents said the school's approach fit their child's learning style. One stated, "I felt that our daughter was well suited [to the approach], being a very free-spirited child who tended to enjoy independent thinking rather than a more structured atmosphere.” Other aspects of fit concerned parents' desire for an education-based daycare or the school's convenient location. 
Another 29.7\% ( $n=19)$ of these respondents indicated that other available options did not fit their child's needs or undermined their learning, for reasons such as instructional approaches used, the classroom or social environment, or lower quality of education. One respondent explained, "The behavior modification system in public education was discouraging and taught terrible lessons of shaming to young kindergarten aged children.” Another wrote:

My child was bored in public school with the worksheets, lectures, and writing assignments that had to be nonfiction. She began to stop really paying attention and fell behind. The interesting thing was that her teachers did not feel that she was not grasping important concepts and insisted that she was pulling average.... I just didn't understand why the children were not challenged more.

\section{Anticipated Valuable Outcomes}

Fifty of the 124 respondents (40.3\%) reported choosing to send their child to Montessori school because of the outcomes the parents anticipated (and valued) from Montessori education (see Table 4). The leading anticipated outcome was academic self-efficacy $(70.0 \%, n=35)$, followed by valuable competencies $(32.0 \%, n=16)$, and self-actualization and enhanced general success $(14.0 \%, n=14)$.

Table 4

Anticipated Outcomes From Montessori Education Influencing Choice of School ( $\mathrm{n}=50)$

\begin{tabular}{lcc}
\hline \multicolumn{1}{c}{ Outcome } & $n$ & $\%$ \\
\hline Academic self-efficacy & 35 & 70 \\
$\quad$ Intrinsic motivation to learn (15) & & \\
$\quad$ Enjoyment of learning (10) & & \\
$\quad$ Learning autonomy (9) & & \\
$\quad$ Self-confidence and self-esteem (8) & \\
$\quad$ Natural curiosity (7) & 32 \\
$\quad$ Self-discipline (5) & & \\
Valuable competencies & & \\
$\quad$ Social skills (7) & & \\
$\quad \begin{array}{l}\text { Progressive cognitive development (e.g., abstract thinking, } \\
\quad \text { computational ability) (4) }\end{array}$ & \\
$\quad$ Sense of context (4) & & \\
$\quad$ Various knowledge areas (3) & 7 & 14 \\
Self-actualization and enhanced general success
\end{tabular}

Note. Parents' open-ended responses were analyzed, and some parents' responses corresponded to two or more principles.

Regarding academic self-efficacy, respondents expressed the desire for their child to develop an intrinsic motivation to learn ( $n=15)$, learning autonomy $(n=9)$, self-confidence and self-esteem $(n=8)$, natural curiosity $(n=7)$, and self-discipline $(n=5)$. One respondent noted, "I believe that a student-led environment in which a child can master a skill at their own pace will foster the child's innate love for learning, which will serve them well throughout life." Another elaborated, "I want my children to enjoy, understand, embrace, grow, learn about the world and to solve problems through the intrinsic motivation of the power of their own capacity to discover and understand." Yet another wrote, "[I] understood the value of self-reliance and independence from a friend that sent her daughter to our Montessori school.”

Respondents identified several competencies that they wanted their child to develop and that they believed would be cultivated in Montessori schools. These include social skills $(n=7)$; cognitive 
development, such as progressing from conceptual to abstract thinking $(n=4)$; sense of context, such as connections between history and science $(n=4)$; and a wide range of other skills and knowledge, such as public speaking, foreign language, or music $(n=3)$. One respondent said, "We wanted her to learn how to appropriately socialize with peers and make friends," while another commented, "I appreciate that the Montessori experience encourages critical thinking and problem-solving.”

Finally, the seven respondents who asserted their belief that Montessori education would support their child's self-actualization and general success cited outcomes such as achieving full potential and becoming independent thinkers. One respondent explained, "I believe that this [focus on cultivating independent thinking], and the development and empowerment of intellect in this way, will most fully and powerfully help them to develop into the truest, best, and most productively impactful versions of themselves." Another respondent added, "I also heard that a Montessori education could really prepare my children to succeed in life and create a firm structure for their future education."

\section{Attraction to Montessori Classroom}

The final reason respondents reported choosing Montessori education was their attraction to the Montessori classroom ( $n=40,32.3 \%)$. Twenty-four (60\%) respondents emphasized their appreciation for the positive, calm, and respectful classroom environment they witnessed in their schools (see Table 5). One respondent explained, "I felt that Montessori would provide a friendly and less distracting environment than our public school.... Our son suffered from anxiety and we wanted to put him in a setting where he...wouldn't be judged or poked fun at.”

Table 5

Classroom Features Prompting Parents to Choose Montessori $(\mathrm{n}=40)$

\begin{tabular}{lrc}
\hline \multicolumn{1}{c}{ Feature } & \multicolumn{1}{c}{$n$} & $\%$ \\
\hline Positive, calm, and respectful classroom environment & 24 & $60.0 \%$ \\
Mixed-age classrooms & 10 & $25.0 \%$ \\
Peer learning and mentoring & 10 & $25.0 \%$ \\
Focus on developing the whole child & 5 & $12.5 \%$ \\
Freedom of movement and time outside & 5 & $12.5 \%$ \\
\hline
\end{tabular}

Note. Parents' open-ended responses were analyzed, and some parents' responses corresponded to two or more principles.

Ten parents (25\%) stated they liked mixed-age classrooms. One said, “Socially it makes sense. A child learns very quickly where they stand in any social situation having experienced being the younger, middle, and older child.” Another 10 participants (25\%) specified that they wanted their child to engage in peer learning and mentoring. One participant explained, "I appreciate that the Montessori experience encourages...collaboration and mentoring with peers.” Another participant addressed how mixed grades and peer collaboration go together: "I also liked that the classroom has mixed grades, so the younger kids learn from the older ones and the older ones reinforce their learning by teaching others." Other attractive elements of the classroom include the focus on developing the whole child, freedom of movement, and time outside; each concept was cited by five (12.5\%) respondents. 


\section{Discussion}

Parents' reasons for choosing one educational option over another have been underexamined to date (Hiles, 2015). The present study produces insights that help fill this gap in research. Study findings indicate that parents chose Montessori education for a small set of reasons. It is notable that two of these reasons concern central aspects of Montessori education-Montessori principles and the Montessori classroom environment - constituting distinct competencies that set Montessori schools apart from other educational options. Administrators are advised to leverage these elements to help attract the families that will thrive in a Montessori setting.

Moreover, a few specific elements were cited by at least one of every four parents: (a) autoeducation, with specific attention to self-directed and independent learning; (b) respect for the child, with specific attention to learning at their own pace; and (c) achieving academic self-efficacy, including the development of intrinsic motivation and joy in learning. These findings underscore a primary focus on the individual child and helping them become a self-motivated, self-managing learner. Study respondents explained that cultivating this approach to education would enhance their child's chances for success in school and in life.

At the same time, it is noteworthy that few of the 124 survey respondents cited the following elements as factors in their decision: focus on developing the whole child (five respondents), allowing freedom of movement and time outside (five respondents), the principles of sensitive periods (three respondents), and the absorbent mind (one respondent). These findings suggest that respondents may not understand the importance of these elements, which is reminiscent of Murray's $(2008,2010)$ conclusion that many adults do not understand the rationale behind the design and structure of Montessori classrooms. Although respondents in this study liked and were attracted to Montessori philosophy, principles, and classroom environments, it is possible they may not fully understand the Method. If parents substantially lack understanding of the Method, it is possible they do not understand the full value of the education or inadvertently encourage their child in ways that are counter to Montessori philosophies, such as using external rewards for good grades or test scores.

\section{Implications for Montessori Administrators}

Study findings indicate that parents' perceptions of fit with the Montessori philosophy or school are a significant factor in their decision to enroll their child. It follows, then, that exploration of fit should be a deliberate part of administrators' discussions with prospective families. This discussion could address topics such as: (a) parents' own experiences with Montessori education or the school, (b) what parents have heard or know about Montessori or the school, (c) their child's learning style and how it compares to the Montessori approach, and (d) their own or their child's perceptions of and experiences with other educational alternatives. Such a discussion could identify any existing sources of dissatisfaction with their child's education and identify how the school may address them. Moreover, study findings suggest that respondents' perceptions of Montessori education - even if not firsthand or about the school in questionplayed a key role in parents' enrollment decisions. Therefore, investing in parental and public awareness about Montessori education may lead to increases in enrollment.

Respondents in this study were attracted to the idea of their child developing as a self-motivated learner while being part of a positive and collaborative community. Montessori principles, methods, and environments support this aim. Thus, prospective parents should be allowed ample time to observe the classroom and school in action and to talk with current students or families to understand how the school fosters students' connection and independence within a caring environment.

Finally, respondents' emphasis on valued outcomes suggests that parents carefully consider the long-term returns on their investment in Montessori education. In addition to their child gaining a wide range of skills and competencies, respondents in this study expected their child to become avid, joyful, and 
independent learners. Administrators should track students' long-term outcomes and make these data and other empirical research about anticipated results of Montessori education available to prospective parents.

\section{Suggestions for Research}

This study has uncovered several important insights about the reasons parents enroll their child in Montessori schools, despite a wide range of educational options. At the same time, study findings point to several areas for future exploration. First, although self-directed learning (auto-education) and working at a child's own pace (respect for the child) emerged as key reasons for choosing Montessori education, few parents cited other Montessori principles (e.g., sensitive periods, absorbent mind) as influences on their decisions. Therefore, the body of research on Montessori education would benefit from further exploration of parents' understanding and awareness of the principles and from examination of the extent to which these principles influence parents' decisions.

A primary reason parents in this study reported choosing Montessori education was the valued outcomes they believed their child would attain. It is important to note that the evidence base for efficacy and outcomes is still thin and continues to develop (Marshall, 2017). Available study findings indicated that Montessori students enjoy learning and working hard (A. Lillard et al., 2017; Rathunde, 2003); experience a more positive classroom community environment (A. Lillard \& Else-Quest, 2006; Rathunde, 2003); exhibit greater academic achievement, social understanding, and mastery orientation (A. Lillard et al., 2017); and perform better in mathematics, language arts, and problem-solving (Dohrmann, 2003; Murray, 2010) than students in traditional school settings do. Other findings indicated mixed results when comparing students from Montessori schools with those in traditional environments (A. Lillard \& Else-Quest, 2006; Lopata et al., 2005; Murray, 2010). Therefore, continued examination is needed to explore the outcomes of Montessori education. Ideally, such research also would examine whether outcomes vary by student characteristics such as learning styles and learning challenges.

A third suggestion for research is to examine why families decide against enrolling in Montessori schools, including both those families who considered Montessori but never enrolled and families who enrolled their child for a period of time (e.g., preschool or elementary school) before withdrawing them and enrolling them in a traditional setting. Parent exit interview data also may help provide insights into this outcome.

\section{Limitations}

This study was based on a small sample of 124 parents from only three schools. Although these data cannot be generalized to all Montessori schools in the United States, findings may transfer to similar Montessori schools.

Moreover, the only demographic information gathered in this survey was the year the respondent first enrolled a child in their Montessori school. Future research should gather the number of children enrolled; parents' age, ethnicity, and education level; and other relevant data. The absence of this information made it difficult to contextualize the current findings.

Additional research should be conducted to confirm the present results. Additionally, the present survey design inherently relied on parents' self-reporting and may not uncover the unconscious and complex motivations that are not easily expressed in this type of design.

\section{Conclusion}

This study's results show that parents choose Montessori education for four primary reasons: attraction to Montessori principles, perceived fit with the Montessori philosophy or school, anticipated outcomes, and attraction to the Montessori classroom. These findings lead to key implications for Montessori schools and their administrators. Specifically, administrators should focus on increasing public 
awareness of Montessori education to help attract prospective parents. Administrators also should thoroughly explore with prospective parents their educational goals for their child; their child's learning needs and preferences; and the nature, benefits, and outcomes of Montessori education to collaboratively examine and confirm school fit, allow parents to experience the unique Montessori environment through multiple contacts with the school, and communicate anticipated child outcomes.

\section{AUTHOR INFORMATION}

Elisabeth Hiles is the program director for the Master of Science in leadership \& administration and Master of Science in sports administration programs at Boston College. She can be reached at elisabeth.hiles@bc.edu.

\section{References}

American Montessori Society. (n.d.). Frequently asked questions about Montessori. Retrieved from http://amshq.org/Montessori-Education/FAQs

Anderson, K. M., \& Resnick, M. A. (1997). Careful comparisons: Public and private schools in America (ED 411 611). National School Boards Association. Retrieved from https://files.eric.ed.gov/fulltext/ED411611.pdf

Chattin-McNichols, J. (1992). The Montessori controversy. Albany, NY: Delmar.

Chertoff, E. (2012, December). The great Montessori schism. The Atlantic. Retrieved from http://www.theatlantic.com/national/archive/2012/12/the-great-montessori-schism/266217/

Dohrmann, K. (2003). Outcomes for students in a Montessori program: A longitudinal study of the experience in the Milwaukee Public Schools. Association Montessori International / USA. Retrieved from https://www.ami-global.org/sites/default/files/Outcomes 1.pdf

Enright, M. (2010). Foundations study guide: Montessori education. The Atlas Society. Retrieved from http://www.atlassociety.org/guide-montessori

Hainstock, E. G. (1997). The essential Montessori: An introduction to the woman, writings, the method, and the movement. New York, NY: Penguin.

Hiles, E. (2015). Measuring parent perception and understanding of Montessori education in three Massachusetts Montessori schools (Doctoral dissertation). Retrieved from ProQuest Dissertations and Theses Global. (UMI No. 3731884)

International Montessori Council. (n.d.) Welcome to the International Montessori Council. Retrieved from https://www.montessori.org/the-international-montessori-council-imc/

Koster-Hale, J., \& Saxe, R. (2013). Functional neuroimaging of theory of mind. In S. Baron-Cohen, M. Lombardo, \& H. Tager-Flusberg (Eds.) Understanding other minds: Perspectives from developmental social neuroscience (3rd ed.), pp. 132-163. New York, NY: Oxford University Press.

Laski, E. V., Vasilyeva, M., \& Schiffman, J. (2016). Longitudinal comparison of place-value and arithmetic knowledge in Montessori and non-Montessori students. Journal of Montessori Research, 2(1), 115. https://doi.org/10.17161/jomr.v2i1.5677

Lillard, A. S. (2012). Preschool children's development in classic Montessori, supplemented Montessori, and conventional programs. Journal of School Psychology, 50, 379-401. doi:10.1016/j.jsp.2012.01.001

Lillard, A. S., \& Else-Quest, N. (2006). Evaluating Montessori education. Science, 313, 1893-1894. doi:10.1126/science.1132362

Lillard, A. S., \& Heise, M. J. (2016). Removing supplementary materials from Montessori classrooms changed child outcomes. Journal of Montessori Research, 2(1), 16-26. https://doi.org/10.17161/jomr.v2i1.5678

Lillard, A. S., Heise, M. J., Richey, E. M., Tong, X., Hart, A., \& Bray, P. M. (2017). Montessori preschool elevates and equalizes child outcomes: A longitudinal study. Frontiers in Psychology, 8, 1-19. https://doi.org/10.3389/FPSYG.2017.01783 
Lillard, P. P. (1997). Montessori in the classroom. New York, NY: Schocken.

Lopata, C., Wallace, N. V., \& Finn, K. V. (2005). Comparison of academic achievement between Montessori and traditional education programs. Journal of Research in Childhood Education, 20(1), 5-13. https://doi.org/10.1080/02568540509594546

Marshall, C. (2017). Montessori education: A review of the evidence base. npj Science of Learning, 2, 1-9. doi:10.1038/s41539-017-0012-7

Miles, M. B., Huberman, A. M., \& Saldaña, J. (2013). Qualitative data analysis. Thousand Oaks, CA: SAGE.

Montessori, M. (1995). The absorbent mind. New York, NY: Henry Holt.

Morrison, G. S. (2014). Early childhood education today (13th ed.). New York, NY: Pearson.

Murray, A. K. (2008). Public perceptions of Montessori education (Doctoral dissertation). Available from ProQuest Dissertations \& Theses Global. (UMI No. 3297628).

Murray, A. K. (2010). Overview of research on Montessori education: An evidence-based curriculum. American Montessori Society. Retrieved from https://amshq.org/ /media/46C230AC87F8472E9FE2B46E555A9D28.ashx

Murray, A. K. (2012). Public knowledge of Montessori education. Montessori Life, 24(1), $18-21$.

National Center for Montessori in the Public Sector. (2014). Growth of public Montessori in the United States: 1975-2014. Retrieved from https://www.public-montessori.org/white-papers/growth-ofpublic-montessori-in-the-united-states-1975-2014/

North American Montessori Teachers' Association. (n.d.). Frequently asked questions about Montessori education. Retrieved from http://www.montessori-namta.org/FAQ/Montessori-Education

Perry, S. (2016, January 25). "Prince George effect" on Montessori schools: Interest among parents up a whopping 65 percent. People. Retrieved from http://www.people.com/people/package/article/0,20395222_20982199,00.html

Povell, P. (2010). Montessori comes to America: The leadership of Maria Montessori and Nancy McCormick Rambusch. Lanham, MD: University Press of America.

Rathunde, K. (2003). A comparison of Montessori and traditional middle schools: Motivation, quality of experience, and social context. The NAMTA Journal, 28(3), 12-52. Retrieved from https://www.ami-global.org/sites/default/files/RathundeComparison.pdf

Schmidt, M., \& Schmidt, D. (2009). Understanding Montessori: A guide for parents. Indianapolis, IN: Dog Ear Publishing.

Seldin, T., \& Davies, V. (2006). How to raise an amazing child the Montessori way. New York, NY: DK Publishing.

U.S. Department of Education, National Center for Education Statistics. (2016a). Table 205.10. Private elementary and secondary school enrollment and private enrollment as a percentage of total enrollment in public and private schools, by region and grade level: Selected years, fall 1995 through fall 2015. In U.S. Department of Education, National Center for Education Statistics (Ed.), Digest of Education Statistics (2016 ed.). Retrieved from https://nces.ed.gov/programs/digest/d16/tables/dt16_205.10.asp

U.S. Department of Education, National Center for Education Statistics. (2016b). Table 214.10. Number of public school districts and public and private elementary and secondary schools: Selected years, 1869-70 through 2014-15. In U.S. Department of Education, National Center for Education Statistics (Ed.), Digest of Education Statistics (2016 ed.). Retrieved from https://nces.ed.gov/programs/digest/d16/tables/dt16_214.10.asp

U.S. Department of Education, National Center for Education Statistics. (2016c). Table 214.40. Public elementary and secondary school enrollment, number of schools, and other selected characteristics, by locale: Fall 2011 through fall 2014. In U.S. Department of Education, National Center for Education Statistics (Ed.), Digest of Education Statistics (2016 ed.). Retrieved from https://nces.ed.gov/programs/digest/d16/tables/dt16_214.40.asp

Whitescarver, K., \& Cossentino, J. (2008). Montessori and the mainstream: A century of reform on the margins. Teachers College Record, 110, 2571-2600. 